\title{
David Oliver: Towards a GP consensus on the future of UK general practice
}

\author{
David Oliver consultant in geriatrics and acute general medicine
}

Berkshire

As a hospital doctor, I rarely write about general practice unless it's to defend, celebrate, or support it. Primary care is the engine room of the NHS and underpins its equity, efficiency, and access. But it's underfunded, understaffed, and overstretched by rising demand. ${ }^{1}$

I'm breaking my "no primary care columns" rule and asking where GPs themselves think that UK general practice should go next. I speak to and read pieces by many GPs, and I see universal agreement that general practice needs better funding and staffing. I admired the clarity of the Royal College of General Practitioners' paper on The 2022 GP: a Vision for General Practice in the Future $N H S^{2}$ and have been enlightened by many of the college's campaigns and resources.

But general practice and its local and national leadership form a broad church with a broad range of views and ideologies. Enthusiastic GP innovators and entrepreneurs advocate new models of care, such as federations, ${ }^{3}$ accountable care organisations, "primary care home" models, ${ }^{5}$ or bespoke services for segmented patient groups. ${ }^{6}$ NHS England's lead GP discussed the need to "end the wild west of primary care." Others enthuse about telemedicine, ${ }^{8}$ supported self management, ${ }^{9}$ and social prescribing. ${ }^{10}$

Ever more GPs say that they actively prefer salaried, flexible, part time roles and wouldn't embrace full partnership

These models all advocate for more care to be delivered away from hospitals. But many GPs consider current patient volumes unsafe or unmanageable and believe that more care being devolved to general practice means that complex patients, formerly managed in hospitals, are being forced into the community or care homes with no extra resources. ${ }^{11}{ }^{12}$

On the partnership model, the recent House of Lords committee on NHS sustainability argued that the current model was "broken and unfit for purpose." ${ }^{13}$ Some GPs have publicly referred to the "corner shop" model of general practice having had its day. ${ }^{14}$ Ever more GPs say that they actively prefer salaried, flexible, part time roles and wouldn't embrace full partnership. ${ }^{15}{ }^{16}$ Yet many defend the traditional, independent contractor partnership model as the guarantor of GPs keeping a personal stake in ensuring quality and value. ${ }^{17}$ They see partnership as a bulwark against contracts being shifted to private providers en masse. ${ }^{18}$ In this view, this model isn't broken-it just needs adequate resources. $^{19}$

In terms of alternative funding models, some GP leaders are beginning to argue for some direct patient payments, while others are resolutely opposed. ${ }^{20}$ Some GPs welcome the government's GP Five Year Forward View, ${ }^{21}$ so long as the government keeps its side of the bargain, while others believe that it falls short of what's needed and that GPs weren't adequately consulted. ${ }^{22}$

Doctrinal differences seem to exist between GP leaders in NHS England, the National Association of Primary Care, the BMA, local medical committees, and campaigning organisations such as GP Survival.

And there's a mismatch between those who argue that general practice is the most rewarding career in medicine ${ }^{23}$ and those who are leaving it, contemplating leaving, or reporting burnout and low morale. ${ }^{2425}$

I realise that, in such a large workforce accounting for over a third of medical staff, there's as much diversity of views as you'd find among hospital doctors. But a consistent, aligned set of messages from all parties would help those of us non-GPs who respect and value general practice to support its vital cause. So, I'd like to ask where GPs think UK general practice should go next. Bring on the rapid responses!

Competing interests: See www.bmj.com/about-bmj/freelancecontributors/david-oliver.

Provenance and peer review: Commissioned; not externally peer reviewed.

Follow David on Twitter: @mancunianmedic

King's Fund. Understanding pressures in general practice. May 2016. https://www. kingsfund.org.uk/sites/files/kf/field/field_publication_file/Understanding-GP-pressuresKings-Fund-May-2016.pdf. 
2 Royal College of General Practitioners. The 2022 GP: a vision for general practice in the future NHS. 7 May 2013. www.rcgp.org.uk/policy/rcgp-policy-areas/general-practice-2022. aspx.

3 Rosen R. Transforming general practice: what are the levers for change? Nuffield Trust. Jun 2015. https://www.nuffieldtrust.org.uk/files/2017-01/1484141771_transforming-generalpractice-levers-change-web-final.pdf.

4 Marshall M. NHS Integration: can accountable care organisations deliver a truly GP-led NHS? GP 14 Dec 2015. http://www.gponline.com/nhs-integration-accountable-careorganisations-deliver-truly-gp-led-nhs/article/1376796.

5 National Association of Primary Care. Primary care home rapid test sites. www.napc.co. uk/rapid-test-sites.

6 Trivedi S. Segment the population to enable better integrated care[article]. Health Serv J 2014;357. https://www.hsj.co.uk/sectors/commissioning/segment-the-population-toenable-better-integrated-care/5077116.

7 Thomas R. Exclusive: NHS England wants to end "wild west" primary care[article]. Health Serv J 2017;357. https://www.hsj.co.uk/home/news/exclusive-nhs-england-wants-to-endwild-west-primary-care/7016994.

8 Chan S. Future of general practice is digital: Dr Shahid Ali interview. GP 1 Jul 2015. www. gponline.com/future-general-practice-digital-dr-shahid-ali-interview/article/1354236.

9 Coalition for Collaborative Care. http://coalitionforcollaborativecare.org.uk/aboutus/.

10 Everington S. Creating a community-based primary care model. King's Fund. 18 Oct 2016. https://www.kingsfund.org.uk/audio-video/sam-everington-community-based-primarycare-model.

11 Gayle D. GPs defend decision to stop looking after care home residents. Guardian 1 Feb 2016. https://www.theguardian.com/society/2016/feb/01/gps-defend-decision-to-stoplooking-after-care-home-residents.

12 Rimmer A. GPs must push back against work dumped on them by hospitals, say GPs. BMJ Careers 20 Apr 2017. http://careers.bmj.com/careers/advice/GPs_must_push_back_ against_work_dumped_on_them_by_hospitals\%2C_says_BMA.

13 lacobucci G. GP partnership model is "no longer fit for purpose," says Lords inquiry. BMJ 2017;357:j1713. doi:10.1136/bmj.j1713 pmid:28381399.

14 Lewis D, Perry J. Future of general practice: A vision of a new way of working for primary care. GP 17 Oct 2016. www.gponline.com/future-general-practice-vision-new-workingprimary-care/article/1412126.
15 Clews G. London GPs at breaking point as a third of practices consider closing. GP 15 Jul 2016. www.gponline.com/london-gps-breaking-point-third-practices-consider-closing/ article/1402492.

16 Dr Zoe Norris Speech to LMC Conference 2017 in full. GP 18 May 2017. http://www. gponline.com/dr-zoe-norris-speech-Imc-conference-2017-full/article/1433961.

17 Royal College of General Practitioners. GP Partnership model is still relevant and brings important benefits for patients. 5 Apr 2017. www.rcgp.org.uk/news/2017/april/gppartnership-model-is-still-relevant-and-brings-important-benefits-for-patients.aspx.

18 Letter from Doctors for the NHS: we need to stop the privatisation of GP services[article] Pulse 2016;357. www.pulsetoday.co.uk/views/letters/we-need-to-stop-the-privatisationof-gp-services/20032855.article.

19 BMA. Chaand Nagpaul speech to BMA LMC conference 2017. 30 May 2017. https://www. bma.org.uk/collective-voice/committees/general-practitioners-committee/lmc-conference/ chair-speech.

20 Jones D, Loader N. Should patients pay to see the GP?BMJ 2016;357:h6800. doi:10. 1136/bmj.h6800 pmid:26740244.

21 Royal College of General Practitioners. GP forward view interim assessment. Feb 2017. Available at www.rcgp.org.uk/policy/general-practice-forward-view.aspx.

22 Lind S. GPs "excluded" from consultations over secret plans for general practice[article]. Pulse 2016;357. www.pulsetoday.co.uk/home/finance-and-practice-life-news/gps-excludedfrom-consultations-over-secret-plans-for-general-practice/20032477.article.

23 Millett D. General practice offers "fulfilling, exciting and purposeful" career. GP 7 Jan 2016. www.gponline.com/general-practice-offers-fulfilling-exciting-purposeful-career/ article/1378479.

24 Sansom A, Calitri R, Carter M, Campbell J. Understanding quit decisions in primary care: a qualitative study of older GPs. BMJ Open 2016;357:e010592. doi:10.1136/bmjopen2015-010592 pmid:26895989.

25 GP recruitment crisis intensifies as vacancies soar to $12.2 \%$. Guardian 12 May 2017. https://www.theguardian.com/society/2017/may/12/gp-recruitment-crisis-intensifies-asvacancies-soar-to-122.

Published by the BMJ Publishing Group Limited. For permission to use (where not already granted under a licence) please go to http://group.bmj.com/group/rights-licensing/ permissions 